\title{
Molecular analysis of the operon which encodes the RNA polymerase sigma factor $\sigma^{54}$ of Escherichia coli
}

\author{
David H. A. Jones, † F. Christopher H. Franklin and \\ Christopher M. Thomas
}

Author for correspondence: Christopher M. Thomas. Tel: +4421414 5903. Fax: +44 214145925.

School of Biological Sciences, University of Birmingham, PO Box 363, Birmingham B15 2TT, UK
The rpoN gene (encoding the sigma factor $\sigma^{54}$ ) of Escherichia coli was cloned and its nucleotide sequence determined. Promoter probe analysis confirmed the presence of a promoter in a $350 \mathrm{bp}$ fragment covering the start of rpoN. The likely promoter was identified. The nucleotide sequence of the region extending $2 \cdot 1 \mathrm{~kb}$ downstream of rpo $\mathrm{N}$ was also determined. This region contained four open reading frames encoding potential polypeptides of 10750 , 17 959, 32492 and $9810 \mathrm{Da}$; maxicell and T7 promoter studies showed that four polypeptides of similar molecular masses were expressed from this region. The amino acid sequence of the 17959 Da polypeptide showed homology to the enzyme IIA domains of several proteins of the bacterial sugar phosphotransferase system (PTS), and the 9810 Da polypeptide showed homology to the HPr proteins of the bacterial PTS. The proteins encoded downstream of rpoN are known to negatively regulate $\sigma^{54}$ activity. The homologies therefore suggest that this effect on $\sigma^{54}$ may be mediated by sequential protein phosphorylation and suggest that there is a link between signal transduction and transcription of $\sigma^{54}$-dependent genes.

Keywords: $r p o N$, sigma factor, sugar phosphotransferase system, signal transduction, Escherichia coli

\section{INTRODUCTION}

The Eschericbia coli rpoN gene encodes the novel RNA polymerase sigma factor $\sigma^{54}(\mathrm{~N} \operatorname{tr} \mathrm{A}, \mathrm{G} \ln \mathrm{F})$. This sigma factor was first identified in enteric bacteria as being responsible for the transcription of nitrogen-regulated genes such as glutamine synthetase and the nitrogen fixation genes (Hirschman et al., 1985; Hunt \& Magasanik, 1985; de Bruijn \& Ausubel, 1983). It has since been shown that a diverse range of genes are transcribed by core RNA polymerase associated with $\sigma^{54}$ (reviewed in Kustu et al., 1989). These include the $f d h F$ gene of E. coli (Birkman $\ell$ t al., 1987), the product of which is responsible for the anaerobic degradation of formate, the $x y l A B C$ genes of Pseudomonas putida (Dixon, 1986) and the pilin gene of $P$. aeruginosa (Ishimoto \& Lory, 1989). Most $\sigma^{54}$ dependent promoters so far described contain a conserved

†resent address: Laboratory of Protein Structure, National Institute for Medical Research, Mill Hill, London NW7 1AA, UK.

Abbreviation: PTS, phosphotransferase system.

The GenBank accession number for the nucleotide sequence reported in this paper is Z27094. motif of GG-10 bp-GC, and require an activator protein for transcriptional activity.

The $r_{0} N$ gene has been cloned and sequenced from a number of bacteria including Klebsiella pneumoniae (Merrick \& Gibbins, 1985), Azotobacter vinelandii (Merrick et al., 1987), Rbizobium meliloti (Ronson et al., 1987; van Slooten et al., 1990), Rhodobacter capsulatus (Jones \& Haselkorn, 1989), Pseudomonas putida (Inouye et al., 1989; Kohler et al., 1989), Thiobacillus ferrooxidans (Berger et al., 1990), Escherichia coli (Sasse-Dwight \& Gralla, 1990), Bradyrbizobium japonicum (Kullik et al., 1991), Salmonella typhimurium (Popham et al., 1991), Alcaligenes eutrophus (Warrelmann et al., 1992), Caulobacter crescentus (Brun \& Shapiro, 1992) and Rbodobacter sphaeroides (Meijer \& Tabita, 1992). A homologue has also been cloned from Bacillus subtilis (Debarbouille et al., 1991). All show a high degree of homology. The E. coli rpo $N$ has been shown to lie between 3411 and $3413 \mathrm{~kb}$ on the E. coli physical map (Merrick et al., 1993). In most cases the nucleotide sequences of the regions downstream of the rpoN ORF are also highly conserved between bacteria. Sequence data are most extensive for K. pneumoniae (Merrick \& Coppard, 
purative promoter

$\begin{array}{ccc}10 & -35 \text { box } 30 & \text { ORFo stop }-10 \text { box }\end{array}$

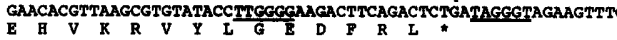
$70 \mathrm{rbs} \quad 90$ moN start ACATGAAGCAAGGTTTGCAACTCAGGCTTA $130 \quad 150 \quad 170$ San/Hincll GCCAACAACTGGCGATGACGCCACAGCTCCAACAGGCAATTCGTCTGTTGCAGTTGTCG

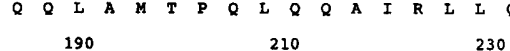

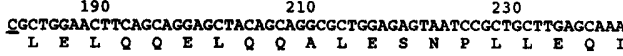
250
TCGACACTCATGAAGAAATCGACACCCGCAAACGCAAGACAGTGAACGCTGGACACCG $310330 \quad 350$

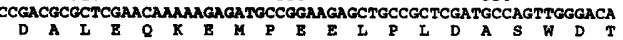
$\begin{array}{llllllll}370 & 390 & & 410 & & & \end{array}$ CCATTTACACCGCTGGTACACCATCCGGCACCAGCGGTGACTACATTGACGACGAGCTGC

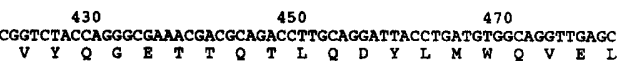
$490 \quad 510 \quad 530$

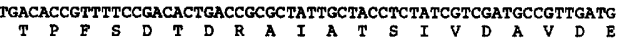
$550 \quad 570 \quad 590$ T G Y L T V P L E D I L E S I G D E E I

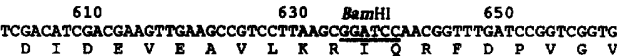
670 BgII
TGGCGGCAMAMGTCTECOTGACTGTCTECTCATCCAACTCTCCCAATTCGATAAGACCA TGGCGGCANAMGATCTCCOTGACTGTCTCCTGATCCAACTCTCCCAATTCGATAAGACCA $730 \quad 750$

CGCCGTGGCTGGAAGAGGCCAGACTGATCATTAGCGATCATCTCGATCTGTTAGCCAATC 790
ACGACTTCCGCACTTTAATGCGCGTCACGCGTCTGAAAGAAGATGTGCTGAAAGAAGCCG
D F R T L M R V T R L K E D V L K E R V 850
TCAATCTGATCCAGTCGCTCGATCCGCGCCCCGGGCAGTCGATCCAGACTGGCGACCTG TCAATCTGATCCAGTCGCTCGATCCGCGCCCCGGGCAGTCGATCCAGACTGGCGAACCTG $910 \quad 930 \quad 950$

AGTATGTCATTCCAGATGTGCTGGTGCGTAAGCATAACGGTCACTGGACGGTAGAACTCA $970990 \quad 1010$

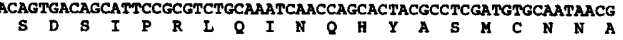
$\begin{array}{ccc}1030 & 1050 & \text { PSt } 1070 \\ \text { CGCGCAACGATGGTGACAGCCAGTTPATCCGCAGCAATCTGCAGGATGCCAAATGGTTGA }\end{array}$ 1090 D Q P I R S N I Q D K K L I

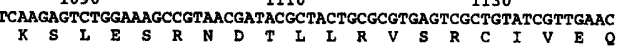

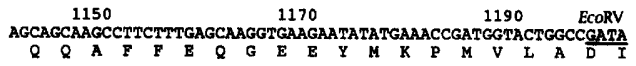
1210
1230 ECORV 1250
TCGCCCAGGTGTCGAAATGCATGAATCGACGATATCTCGCGTGACCACGCAAAATACC TCGCCCAGGCTGTCGAAATGCATGAATCGACGATATCTCGCGTGACCACGCAAAMATACC

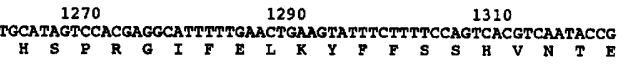

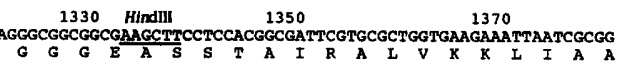
1390
CGGAAACCCAGCGAACCGTTGAGCGACAGCMAGTTAACCTCTTTGCTGTCGGAACAAG D N P A X P D

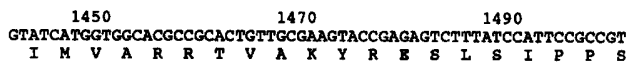

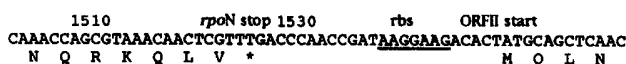
$1570 \quad 1590 \quad 1610$ ATTACCGGAAATAACGTCGAGATCACCGAGGCACTGCGCGAATTTGTTACAGCCAAATTT

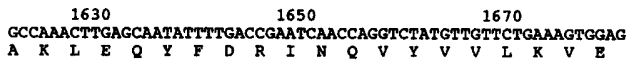
$1690 \quad 1710 \quad 1730$ AAAGTCACCCACACCTCAGATGCAACACTGCATGTAAACGGTGGTGAATTCATGCCAGC 1750
GCGGAAGGCAGGACATGTACGCTGCCATTGATGGCTTAATTGATAAGCTGGCACGCCAG A E G Q D M Y A A I D G L TTGACCAAACATAAAGATAAACTGAAACAACACTAATTGTCCGGGCAATTAGCATGTGCA L $\stackrel{1870}{1890} \quad 1910$ 1930 rbs 1950 ORFIII start 1970 ACTGTTGMGGGCGGTTCTAGTGAAATTATGACAAATAATGATACAACTCTACA 299020102030 CTTAGCAGTGTTCTTAACAGGGATGTACGCGAAGCGCGTCCACTGTCAGAGCAAAAA $20502070 \quad 2090$ 2110213022150 Ge A I I T R B M G T G I G G I 2170 2190 2210

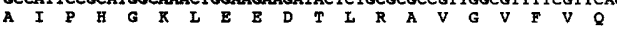
2230
CTCGAAACGCTATAGCTTTCGATGCCATCGACAACCAACCGGTGGACTTACTTTTTGCC $229023310 \quad 2330$ CTGCTGGTGCCGGCAGACCAAACTAAAACGCACCTGCATACTCTGTCGCTGGTGGCGAA

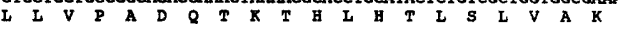

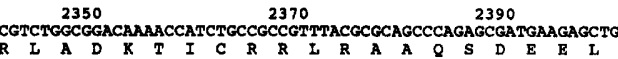
$\begin{array}{cc}2410 & 2430 \\ \text { TATCAAATCATTACGGATACCGAAGGTACTCCGGATGAAGCGTAGTTATTCGGTAATGTC }\end{array}$ 2470
TCTTTTAGACGTTGTGAGGAGAACAGTACATGGTACTGATGATCGTCAGCGGACGTTCA $M$ V M I V S G R S

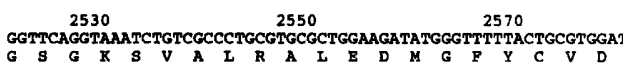
2590
AACCTYCCCGTAGTGTTGTACCCGATCTGGCTCGAACCCTGGCCGATCGCGAGATTTCT

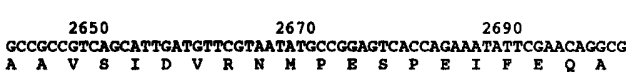

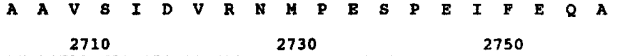
ATGAGTAACCHGCCTGACGCTITCTCACCGCAACTCCTGTTCCTGGATGCCGACCGTAA 2770
2790
ACCTTAATTCGTCGTTACAGTGACACGCGCCGACTGCATCCGCTTTCCAGCAAAAACCTG 2830288502870

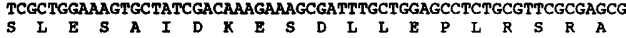
$28902910 \quad 2930$ GATCTGATTGTCGATACCTCAGAAATGTCCGTTCACGAGCTGGCTGAAATGCTGCGTACC 295029702990 CGTCTGCTCGGTAAACGTGAACGCGAACTGACCATGGTCTTTGAGTCTTTCGGCTTCAAA 3010 Clal $3030 \quad 3050$

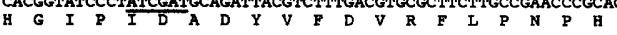
3090
TamHI 3070
TGGATCCGAACTGCGTCCAATGACAGGTCTTGATAAACCTGTCGCCGCGTTCCTCGAC 3130
CGCCACACAGAGGACACAATTTATCTACCAGACGCGAGCTATCTTGAGCTATGGTTA CGCCACACAGAAGTACACAATTTTATCTACCAGACGCGAAGCTATCTTGAGCTATGGTTA 3190
CCTATGCTGGAAACCAACAACCGTAGCTACTTGACGGTCGCCATTGGTTGTACCGGCGGG
P 3250
AAGCACCGTTCGGTGTATATTECAGAGCAACTGGCAGACTACTTCCGCTCGCGCGGTAAR $3310 \quad 3330$ rbs ORFV starvORFIV stop

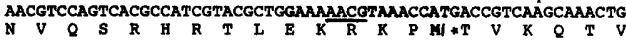$$
3370 \quad 3390 \quad 3410
$$$$
\text { E I T N K I G M H A R R A M K L F F E }
$$$$
3430 \text { 3450 } 3470
$$$$
\text { Q G F D A E V L L L R N D E G T E A E A }
$$$$
3490 \quad 3510 \quad 3530
$$$$
\text { ACAGCGTTATTGCGCTGCTGATGTTGGATTCTGCCAAAGGACGGCAGATTGAAGTTGAAG }
$$$$
3550 \quad 3570 \quad 3590
$$$$
\text { T G P Q E E B A L A A V I A L F N S G G }
$$$$
\text { ORFV stop } 3630 \quad 3650
$$

TTGATGAAGATTAATCTTCATCACTTTGACATACAACTCCCTTCAAACTCCCCCCGACAA

TAA

Fig. 1. Nucleotide sequence and amino acid translations of the rpoN operon. Potential ribosome-binding sites (rbs) are indicated, as are restriction sites which were used for subcioning parts of the operon. 
1989) and E. coli (Imaishi et al., 1993). Studies in K. pneumoniae indicated that there are at least three ORFs cotranscribed with $r p o N$, and that they negatively regulate the activity of $\sigma^{54}$ (Merrick \& Coppard, 1989). Sequence similarities led to the suggestion that these downstream genes may provide a means of sensing nutritional state and regulating $\sigma^{54}$ activity by phosphorylation (Reizer $e t$ al., 1992; Imaishi et al., 1993).

In this report we describe the cloning and sequencing of what appears to be the complete E. coli rpoN operon. The sequence of the downstream ORFs which have not been previously analysed strengthens current ideas about how the downstream-encoded polypeptides may regulate $\sigma^{54}$.

\section{METHODS}

Bacterial strains and plasmids. E. coli strain JM83 (YanischPerron et al., 1985) was used for all cloning and manipulations. E. coli strain Q359 (Karn et al., 1980) was used to generate the genomic library, and bacteriophage $\lambda$ EMBL3 (Frischauf et al., 1983) was used as the library vector. E. coli strains CSR603 (Sancar et al., 1978) and JM109 (Yanisch-Perron et al., 1985) were used for maxicell expression and $\mathrm{T} 7$ promoter expression respectively. E. coli $\mathrm{C} 600 \mathrm{~K}^{-}$(McKenny et al., 1981) was used for promoter probe studies. Cultures were grown at $37^{\circ} \mathrm{C}$ in $\mathrm{L}$ broth or M9 (Kahn et al., 1979) media, and penicillin was added to $100 \mu \mathrm{g} \mathrm{ml}^{-1}$ (liquid media) or $300 \mu \mathrm{g} \mathrm{ml}^{-1}$ (solid media) as required.

Plasmid pUC18 (Yanisch-Perron et al., 1985) was used as the standard cloning vector. Plasmids pKO1 and pKO6 (McKenny et al., 1981) were used as promoter probe vectors. Plasmids pGBT30 (tacp; Jagura-Burdzy et al., 1991) and pGEM3Z (T7p; Promega) were used as expression vectors. Plasmid pMM17 (Merrick \& Stewart, 1985), which contains the $K$. pneumoniae $r p o N$, was kindly given by Dr M. Merrick, University of Sussex, UK). Plasmids constructed during the course of this work are described in the appropriate figure.

DNA manipulations. Plasmid DNA was isolated by the alkalineSDS method of Birnboim \& Doly (1979), and whole-cell DNA was prepared according to Frey et al. (1983). Bacteriophage DNA was prepared as described in Sambrook et al. (1989). Enzymes were used according to the manufacturer's instructions and DNA was purified using Gene-clean (Bio101). Other techniques were performed as described in Sambrook et al. (1989).

DNA sequence analysis. DNA sequencing by the chaintermination method (Sanger et al., 1977) was carried out on double-stranded plasmid DNA template using the Sequenase kit (United States Biochemical). Template DNA was purified by $\mathrm{CsCl} /$ ethidium bromide density-gradient centrifugation. Primers were either sequencing or reverse sequencing primers from USB, or $16 \mathrm{mer}$ oligonucleotides synthesized by Alta Bioscience. Nucleotide and amino acid sequences were analysed using the UwGCG programs (Devereux et al., 1984).

Construction of the gene library and screening for rpoN. Total DNA of E. coli Q359 was partially digested with Sau3A and size-fractionated on a sucrose gradient (Frey et al., 1983). DNA fragments of approximately $15-22 \mathrm{~kb}$ were collected and ligated into the BamHI site of bacteriophage $\lambda$ EMBL3. The resulting plaques were screened with the $1.8 \mathrm{~kb}$ ClaI fragment of pMM17 (the $K$. pneumoniae rpoN gene) which had been labelled with $\left[\alpha^{3}{ }^{32} \mathrm{P}\right] \mathrm{dATP}$ (Sambrook et al., 1989). Southern hybridization of DNA fragments separated by gel electrophoresis was performed as described in Sambrook et al. (1989).
Maxicell analysis of polypeptides. E. coli strain CSR603 harbouring the required plasmid was treated essentially as described by Shingler \& Thomas (1984). Labelled polypeptides were analysed by SDS-PAGE (Laemmli, 1970) followed by fluorography.

T7 promoter analysis. An overnight culture of E. coli JM109 containing the test plasmid was diluted 1 in 20 and grown to $\mathrm{OD}_{650} 0.7$ in M9 medium containing $0.4 \%$ glucose and $1 \mathrm{mM}$ thiamin. HCl. Duplicate samples were taken; IPTG was added to one set to $0.5 \mathrm{mM}$ and these were incubated for a further $1 \mathrm{~h}$. Rifampicin was then added to $200 \mu \mathrm{g} \mathrm{ml}^{-1}$ (prepared immediately before use in ethanol) and the culture was shaken at $37^{\circ} \mathrm{C}$ for $80 \mathrm{~min}$. Then $75 \mathrm{ml}\left[{ }^{14} \mathrm{C}\right]$ protein hydrolysate (Amersham cat. no. CFB25) was added to each $1 \mathrm{ml}$ sample, and this was left at $37^{\circ} \mathrm{C}$ for $10 \mathrm{~min}$. Cells were then harvested and a sample of each analysed by SDS-PAGE (Laemmli, 1970) followed by fluorography.

Assay for galactokinase. Assays were performed as described by McKenny et al. (1981).

\section{RESULTS}

\section{Cloning and nucleotide sequence determination of rpoN and flanking regions}

The gene library constructed in $\lambda$ EMBL3 was screened by plaque hybridization using the $1.8 \mathrm{~kb} \mathrm{ClaI}$ fragment of pMM17 (which contains the rpoN homologue of $K$. pneumoniae; Merrick \& Stewart, 1985). From approximately 5000 plaques, eight hybridization-positive plaques were identified and bacteriophage DNA was isolated from these. Restriction mapping showed three related classes of clone. One clone was digested with a variety of restriction enzymes. Southern blotting showed that none gave a single hybridization-positive band, but digestion with $B g / \mathrm{II}$ produced two positive bands, of 4 and $6 \mathrm{~kb}$. These fragments were cloned into the BamHI site of pUC18 to give pRPO4 and pRPO6 respectively. In this way large flanking regions of DNA could be studied, and as the gene would not be intact, any toxic effect of having $r p o N$ at a high copy number could be eliminated.

The nucleotide sequence of the cloned $r p o N$ was determined on both strands (its location assigned by homology to $r p o N$ genes from other bacterial species), and the sequence of upstream and downstream flanking regions was also determined. To ensure that the two Bg/II fragments were contiguous, the region around the BglII site of pMM18 (a plasmid containing the intact $r p o N$ of $E$. coli, kindly provided by Dr M. Merrick) was also sequenced.

The nucleotide sequence is shown in Fig. 1. Downstream of $r p o N$ there are four putative ORFs which are shown in Fig. 1 (designated ORFs II-V). Details of the proteins (designated by $\mathrm{P}$ followed by the number of constituent amino acids) are shown in Table 1 . The protein products of ORFs II and III show high levels of homology to the equivalent proteins of other bacteria. P95 shows $87 \%$ identity to that of the $K$. pneumoniae homologue, dropping to $22 \%$ identity to the R. meliloti homologue. P163 also shows $87 \%$ homology to the $K$. pneumoniae ORFIII homologue.

The potential ribosome-binding sites are indicated in 
Table 1. Features of predicted products of ORFs in the rpoN operon

\begin{tabular}{|lccc|}
\hline & $\begin{array}{c}\text { Molecular } \\
\text { mass (Da) }\end{array}$ & \multicolumn{2}{c|}{ Calculated Calculated } \\
& molecular & pI \\
& (SDS-PAGE) & mass (Da) & \\
\hline$\sigma^{\mathbf{5 4}}($ rpoN) & - & 53902 & $4 \cdot 46$ \\
P95 (ORFII) & 8000 & 10750 & $7 \cdot 09$ \\
P163 (ORFIII) & 19000 & 17959 & $5 \cdot 71$ \\
P284 (ORFIV) & 30000 & 32492 & $7 \cdot 26$ \\
P90 (ORFV) & 11000 & 9810 & $4 \cdot 12$ \\
\hline
\end{tabular}

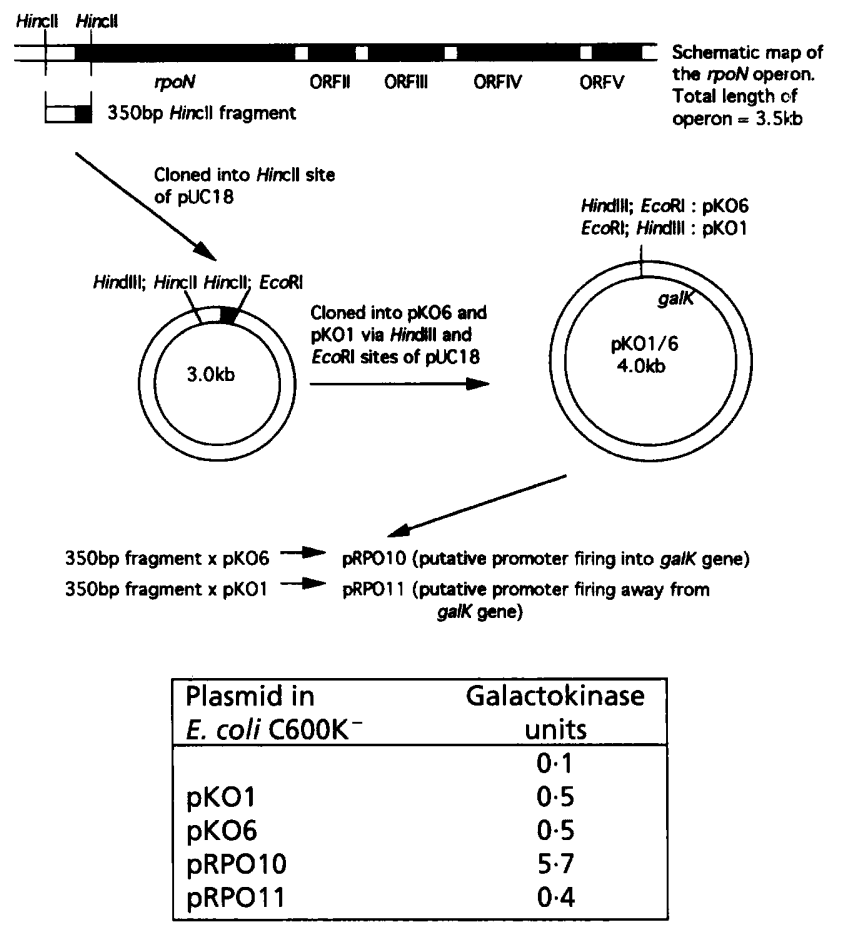

Fig. 2. Construction of plasmids for promoter probe analysis. The table shows the results of assaying galactokinase in $E$. coli $\mathrm{C} 600 \mathrm{~K}^{-}$carrying the promoter probe plasmids.

Fig. 1 , as is a potential $\sigma^{70}$-dependent promoter located upstream of rpoN (see next Results section). A hairpin structure is also indicated which overlaps the stop codon of ORFII and may act to stabilize the mRNA. Downstream of the last ORF is a cytosine-rich region followed by an AT-rich region (bases 3635-3663). This may be indicative of a rho-dependent transcriptional terminator (Alifano et al., 1991). Polypeptide analysis described below indicates that ORFV is the last ORF in this operon.

The sequence of rpoN reported here differs from that reported by Sasse-Dwight \& Gralla (1990). Our sequence has an additional base at position 386 (in Fig. 1) and one less at position 402. This has the effect of producing a frame-shift of five amino acids in the polypeptide. Fig. 1

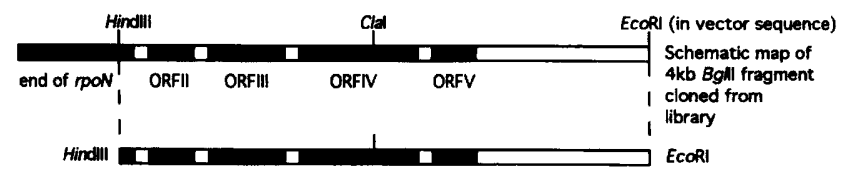

Blunt-end 3.3kb

EcoRl-Hindill fragment with

Klenow
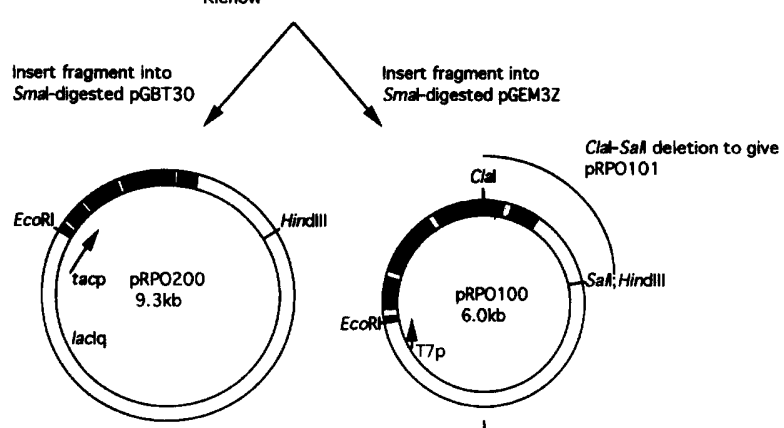

Clat-Sal delet
PRPO101
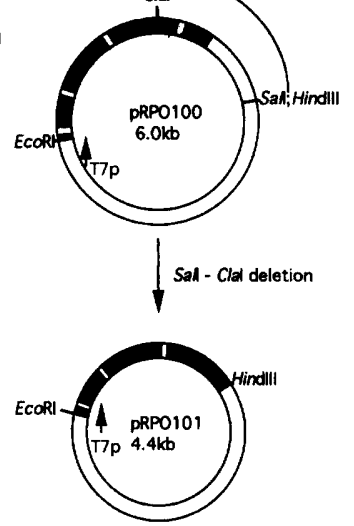

Fig. 3. Construction of plasmids to place ORFs $\|-V$ under the control of tacp and T7p to allow visualization of polypeptides in maxicells or in whole cells in the presence of rifampicin.

also shows the end of a potential reading frame upstream of rpoN. Preliminary data (sequence from one strand only) indicates that this upstream ORF extends at least $550 \mathrm{bp}$ upstream of the indicated stop codon, consistent with analysis reported by Imaishi et al. (1993).

\section{Promoter activity upstream of rpoN}

The start codon for rpoN is contained within a $350 \mathrm{bp}$ Hincll restriction fragment such that $250 \mathrm{bp}$ of DNA upstream of $r p o N$ are present in this fragment. This fragment was cloned into the probe vectors $\mathrm{pKO} 1$ and pKO6 (McKenny et al., 1981) as shown in Fig. 2, allowing promoter activity in both directions to be determined. The assay results (Fig. 2) provide evidence for a promoter upstream of $r p o N$.

A potential $\mathrm{E} \sigma^{54}$ promoter is indicated in Fig. 1. The sequence of the -35 and -10 boxes and the intervening sequence is absolutely conserved between $E$. coli and $K$. pneumoniae and $S$. typhimurium. Outside this region the homology falls between species. It would therefore seem likely that this is the $r p o N$ promoter.

\section{Polypeptides encoded by the rpoN gene}

To test whether the ORFs downstream of $r p o N$ are cotranscribed with rpoN and actually encode proteins, this region was subjected to maxicell and $\mathrm{T} 7$ promoter analysis. 


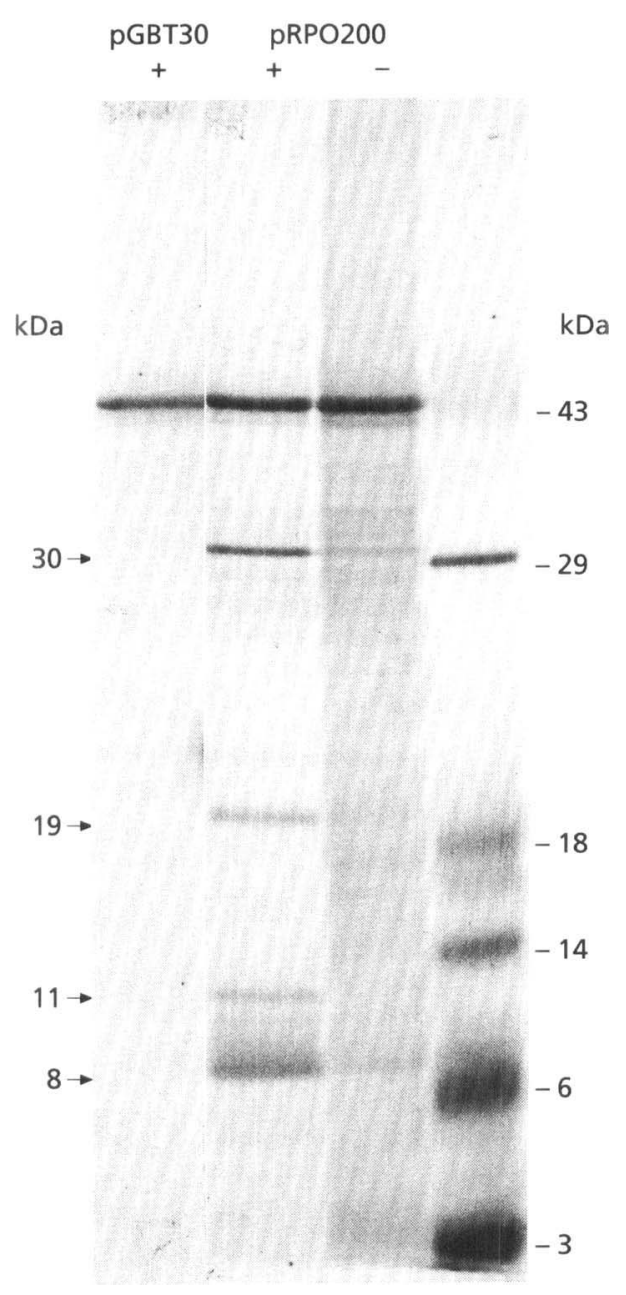

Fig. 4. Autofluorograph showing the result of maxicell analysis of pRPO200. $+/-$ indicates induction with IPTG. Polypeptides of $8,11,19$ and $30 \mathrm{kDa}$ (arrows) are present in the induced pRPO200 sample, but not in the uninduced sample or the negative control.

Plasmid pRPO4 (which contains $0.8 \mathrm{~kb}$ of the rpoN ORF and $3.4 \mathrm{~kb}$ of downstream flanking DNA) was digested with EcoRI and HindIII as shown in Fig. 3. The $3.3 \mathrm{~kb}$ fragment was then treated with DNA polymerase to fill in the single-stranded ends and inserted into pGBT30 (Jagura-Burdzy et al., 1991) or pGEM3Z (Promega) which had been digested with $S m a \mathrm{I}$; the resulting plasmids (pRPO200 and pRPO100 respectively) were then transformed into the requisite strains. Plasmid pRPO200 was then subjected to maxicell analysis and pRPO100 to T7 promoter analysis. Both plasmids showed the same four polypeptide products of $8,11,19$ and $30 \mathrm{kDa}$ (Figs 4 and 5). A deletion was also made in pRPO100 as shown in Fig. 3. This removes the last $1.55 \mathrm{~kb}$ of inserted DNA such that ORFII and ORFIII remain intact and $0.5 \mathrm{~kb}$ of ORFIV remains intact. The result of analysis of this plasmid, pRPO101, is shown in Fig. 5. While the bands of 8 and $19 \mathrm{kDa}$ remain the same, the $30 \mathrm{kDa}$ protein is reduced in size to $24 \mathrm{kDa}$, and the $11 \mathrm{kDa}$ protein disappears. ORFII and ORFIII encode predicted proteins of 10750 and $17959 \mathrm{Da}$ respectively, which are presumably the proteins of 8 and $19 \mathrm{kDa}$ observed experimentally. The polypeptide of $30 \mathrm{kDa}$ which becomes truncated to $24 \mathrm{kDa}$ in pRPO101 is that encoded by ORFIV (encoding a polypeptide of $32492 \mathrm{Da}$ ), as this ORF is truncated to $0.5 \mathrm{~kb}$ in pRPO101, and would terminate in vector sequence. Finally the last ORF (encoding a protein of $9810 \mathrm{Da}$ ) must produce the polypeptide of $11 \mathrm{kDa}$, as this is lost in the deleted plasmid. It is of note that while ORFII produces a larger polypeptide than ORFV, upon electrophoresis it demonstrates a greater mobility. This is accounted for in that the product of ORFV is much more acidic (see isoelectric points in Table 1), so would bind less SDS and run more slowly on SDS-PAGE.

The polypeptide data indicate that the ORFs observed in the nucleotide sequence are cotranscribed with $r p o N$. In addition, no other polypeptide products were seen on any analysis even though pRPO100 and pRPO200 contain ample coding capacity for further ORFs. This would therefore indicate that ORFV is the last ORF of the $r p o N$ operon, consistent with our identification of a likely rhodependent terminator after ORFV (see above).

\section{DISCUSSION}

The work reported in this paper places a promoter to within $260 \mathrm{bp}$ of the $r p o N$ start codon and a probable promoter has been identified which is conserved in the $K$. pneumoniae rpoN gene (Merrick \& Stewart, 1985). This is in agreement with work on the promoter of the R. meliloti $r p o N$, for which the $5^{\prime}$ end of the mRNA was mapped to about 70 bp upstream of the start codon (Albright $e t$ al., 1989). Therefore $r p o N$ could be the first gene in the operon. However, previous studies have also demonstrated the presence of a conserved ORF of unknown function upstream of $r p o N$ in several bacterial species, but with intervening lengths of DNA ranging from $12 \mathrm{bp}$ in T. ferrooxidans (Berger et al., 1990) to $180 \mathrm{bp}$ in R. meliloti and P. putida (Albright et al., 1989; Inouye et al., 1989). Thus in R. meliloti the promoter lies in the region between the two genes but in E. coli the postulated promoter overlaps ORF0 and there is no transcriptional terminator to block transcription across ORF0 entering rpoN.

A potential ribosome-binding site for $r p o N$ is shown in Fig. 1. While this sequence (AGGAGA) would appear to be a near-classical consensus motif, it is situated $14 \mathrm{bp}$ from the start of $r p o N$. This may be a contributing factor in the low level of expression of rpoN (Castano \& Bastarrachea, 1984).

The proposed E. coli $\sigma^{54}$ is a protein of $53902 \mathrm{Da}$. This differs slightly from that reported by Sasse-Dwight \& Gralla (1990) as a result of two frame-shift differences in the DNA sequences (see Results). Many motifs and homologies of $\sigma^{54}$ proteins from other bacterial species have been described previously (Merrick et al., 1987; Sasse-Dwight \& Gralla, 1990) and will not be repeated here. P95 (the product of ORFII) shows $38 \%$ amino acid 
(a)

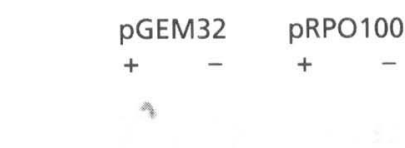

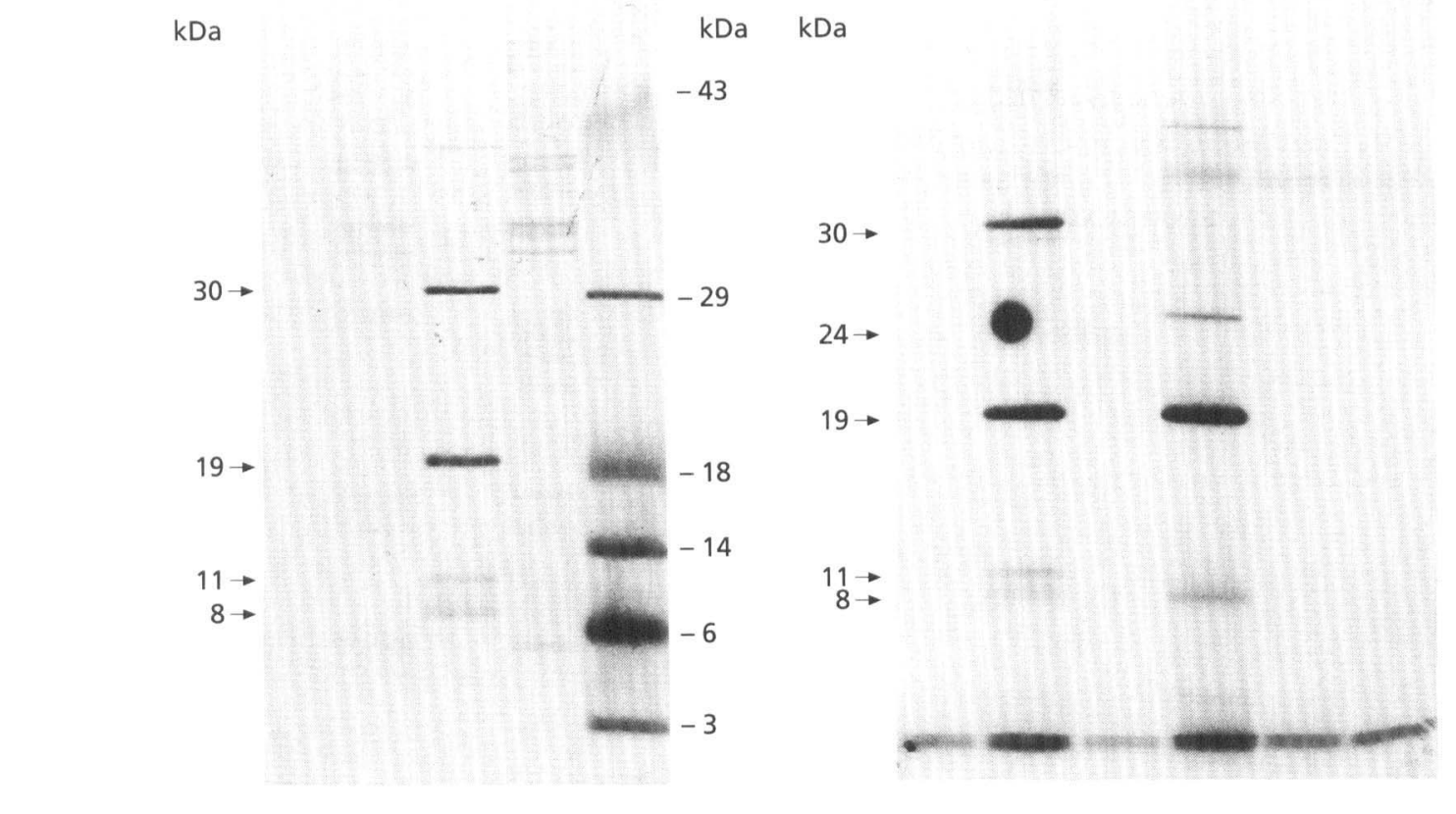

(b)

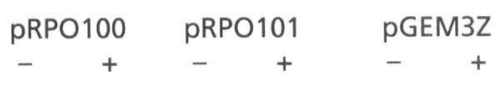

Fig. 5. (a) Autofluorograph showing the result of polypeptide analysis using transcription from the T7p of pRPO100. $+l-$ indicates induction of T7 RNA polymerase with IPTG. Polypeptides of 8, 11, 19 and $30 \mathrm{kDa}$ (arrows) are present in the induced pRPO100 samples. (b) Comparison of polypeptides produced by pRPO100 (see a) with those produced by pRPO101 (the deletion derivative of pRPO100). Polypeptides of 8 and $19 \mathrm{kDa}$ are still present in the pRPO101 sample, but the $11 \mathrm{kDa}$ polypeptide is not present and the $30 \mathrm{kDa}$ polypeptide is reduced in size to $24 \mathrm{kDa}$. These polypeptides are absent from the control pGEM3Z. Molecular mass markers correspond only to panel (a).

identity to the product of an ORF preceding phe $A$ of E. coli (Hudson \& Davidson, 1984); this similarity was previously reported for the $K$. pneumoniae homologue by Merrick \& Coppard (1989).

The genes corresponding to ORFII and ORFIII downstream of rpoN are known to negatively regulate the transcription of $\sigma^{54}$-dependent genes (Merrick \& Coppard, 1989). In view of possible polar effects and the possibility of interactions between products of other downstream genes we should not assume that only ORFII and ORFIII are involved in this regulation. The mode of action of this regulation is unknown. However, the polypeptides encoded by these genes show some interesting homologies which have led to the proposal that these genes sense nitrogen and carbon levels and regulate RpoN by phosphorylation (Reizer et al., 1992). We find that not only the protein encoded by ORFIII (previously observed) but also that encoded by ORFV (not previously observed) show high levels of sequence similarity to domains of the phosphoenolpyruvate:sugar phosphotransferase system (PTS) of bacteria. This system essentially comprises two general proteins, enzyme I and $\mathrm{HPr}$, and the sugar-specific enzyme II complex (Saier \& Reizer, 1992). A phosphoryl group is transferred from phosphoenolpyruvate to enzyme I, to $\mathrm{HPr}$, and then to the enzyme II complex. This complex is responsible for the uptake and concomitant phosphorylation of sugars. Enzyme II can consist of up to four distinct domains, though it commonly comprises a transmembrane domain (IIC) and two hydrophilic domains (IIA and IIB), each containing a sequentially-phosphorylated amino acid residue. Enzyme II may also have domains which serve as the general proteins enzyme I and HPr (Saier \& Reizer, 1992).

P163 (the product of ORFIII) shows sequence similarity to the IIA domains of the fructose-specific enzyme II of $S$. typhimurium and R. capsulatus (Geerse et al., 1989; Wu et al., 1990), and the mannitol-specific enzyme II of E. coli and Stapbylococcus carnosus (Lee \& Saier, 1983; Fischer $e t$ al., 1989). This observation has been previously reported by Reizer et al. (1992) and Imaishi et al. (1993).

We show here for the first time that $\mathrm{P} 90$ (the product of ORFV) shows similarity to the HPr proteins and HPr-like protein domains of the PTS. An alignment of all known HPr sequences with P90 is shown in Fig. 6. The percentage identities that $\mathrm{P} 90$ shows with members of this family range from $37 \%$ (B. subtilis $\mathrm{HPr}$ ) to $25 \%$ (E. coli and S. typhimurium $\mathrm{HPr}$ ) and $19 \%$ (E. faecalis $\mathrm{HPr}$ ). The histidine indicated at position 16 in the $\mathrm{P} 90$ sequence is the 


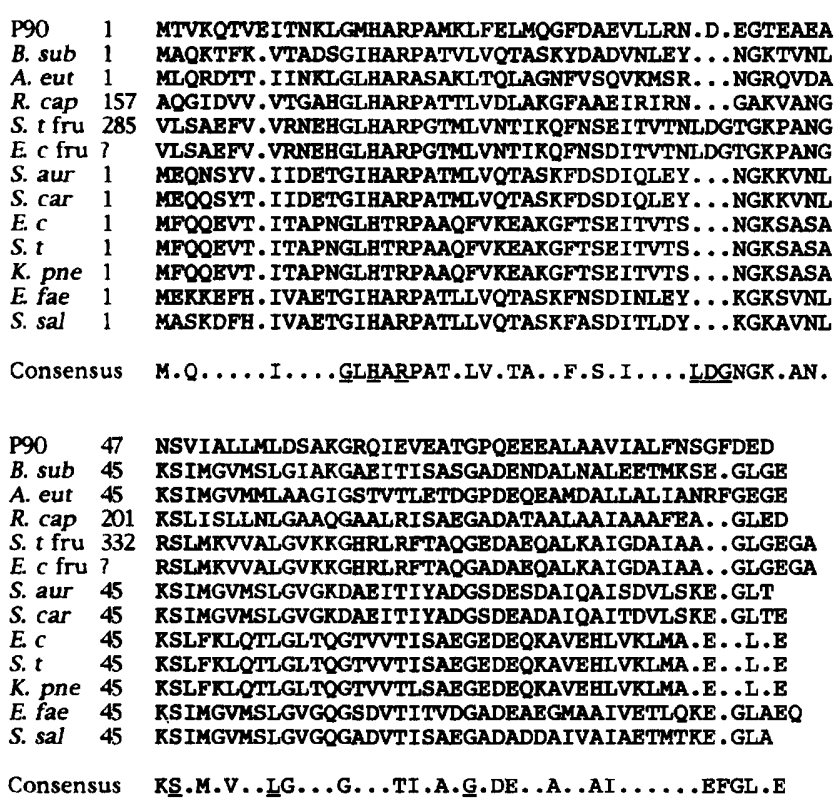

Fig. 6. Alignment of known HPr domain protein sequences including $E$. coli P90. A consensus is shown and invariant residues are underlined. Abbreviations and references are as follows: B. sub, Bacillus subtilis (Gonzy-Treboul et al., 1989); A. eut, Alcaligenes eutrophus (Pries et al., 1991); $R$. cap, Rhodobacter capsulatus (Wu et al., 1990); S. $t$ fru, Salmonella typhimurium (fructose) (Geerse et al., 1989); E. c fru, Escherichia coli (fructose) (Orchard \& Kornberg, 1990); S. aur, Staphylococcus aureus (Reizer et al., 1988); S. car, Staphylococcus carnosus (Eisermann et al., 1991); E. C, Escherichia coli (De Reuse et al., 1985); S. $t$, Salmonella typhimurium (Byrne et al., 1988); K. pne, Klebsiella pneumoniae (Titgemeyer et al., 1990); E. fae, Enterococcus faecalis (Deutscher et al., 1986); S. sal, Streptococcus salivarius (Gagnon et al., 1992; Reizer et al., 1993).

residue which becomes phosphorylated in the PTS pathway. In Gram-positive organisms the serine residue at position 46 in the B. subtilis sequence in Fig. 6 can also be phosphorylated (reviewed in Reizer et al., 1993); however, the HPrs from Gram-positive species show a high degree of similarity around this serine which is not shared by the HPrs of the Gram-negative species (and this includes P90). The three-dimensional structure of $\mathrm{HPr}$ has been determined (Wittekind et al., 1992; Chen et al., 1993), and P90 will presumably have a near-identical structure. It is of note that one protein of the enzyme II complex of the fructose uptake system in S. typhimurium comprises enzyme IIA (to which P163 shows homology) at its $\mathrm{N}$-terminus and $\mathrm{HPr}$ at its $\mathrm{C}$-terminus. Thus $\mathrm{P} 163$ and $\mathrm{P} 90$ are homologous to the two ends of a single protein. Therefore by analogy to the bacterial PTS, P90 would be expected to phosphorylate P163, which itself acts as an intermediary in the transfer of a phosphate group between proteins, possibly to $\sigma^{54}$ itself.

P284 contains a region with similarity to the glycine-rich phosphate-binding loop of many ATP-and GTP-binding proteins (Fig. 7; Walker et al., 1982; Saraste et al., 1990). It is possible that P284 is a kinase which could initiate a chain of phosphorylation steps linking $\sigma^{54}$ to some sort of sensory apparatus. Consistent with this is limited sequence

\begin{tabular}{|c|c|}
\hline nsensus & $\mathbf{G} \times \mathbf{X} \times \mathbf{X} \mathbf{G}$ \\
\hline $\begin{array}{l}\text { P284 (residues } 8-15 \text { ) } \\
\text { E. coli adenylate cyclase } \\
\text { Ras P21 } \\
\text { E. coli EF-Tu } \\
\text { E. coli ATP synthase b-subunit } \\
\text { Rat myosin heavy chain } \\
\text { Chick thymidine kinase }\end{array}$ & 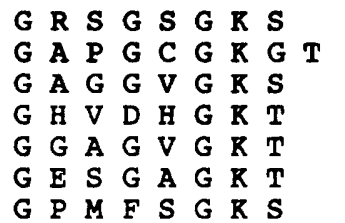 \\
\hline
\end{tabular}

Fig. 7. Sequence similarity of a region of P284 with proteins representing six of the major protein families known to contain a glycine-rich phosphate-binding loop. The consensus sequence for such a motif is also shown. All sequences are taken from Saraste et al. (1990).

similarity to a region of PgtA, an activator of the phosphoglycerate transport system of $S$. typhimurium (Yu \& Hong, 1986), and to NarX, part of a two-component regulatory system which senses nitrate and nitrite concentration (Stewart et al., 1989; data not shown).

The bacterial PTS controls more than just the translocation of sugars across the membrane; it is involved in the regulation of chemotaxis, carbohydrate permeases not otherwise associated with the PTS, catabolic enzymes, transcriptional antitermination and transcriptional regulation (reviewed in Saier, 1993, and accompanying articles). The additional similarities reported in this paper for ORFs IV and V strengthen the idea of a link between carbon metabolism and expression of $\sigma^{54}$-dependent genes, mediated via a phosphorylation pathway. An increasing number of kinases are being found in bacteria, and many responses are known to be mediated by protein phosphorylation. It may be that bacterial signal transduction is not dissimilar to that of eukaryotes, where extracellular signals can activate an elaborate network of intracellular signalling events. In eukaryotic cells a major mechanism of signal integration is that of protein phosphorylation and dephosphorylation, and the control of transcription by such pathways is well established (reviewed in Karin \& Smeal, 1992). We predict that further analysis of this set of genes will reveal a similar system here.

\section{ACKNOWLEDGEMENTS}

We are very grateful to Mike Merrick for helpful suggestions and the gift of pMM17 and pMM18. D.H.A.J. was the recipient of an SERC Biotechnology Directorate CASE studentship.

\section{REFERENCES}

Albright, L. M., Ronson, C. W., Nixon, B. T. \& Ausubel, F. M. (1989). Identification of a gene linked to Rbizobium meliloti ntr $A$ whose product is homologous to a family of ATP-binding proteins. J Bacteriol 171, 1932-1941.

Alifano, P., Rivellini, F., Limanro, D., Bruni, C. B. \& Carlomagno, M. S. (1991). A consensus motif common to all rho-dependent prokaryotic transcription terminators. Cell 64, 553-563.

Berger, D. K., Woods, D. R. \& Rawlings, D. E. (1990). Comple- 
mentation of Escherichia coli $\sigma^{54}(\mathrm{NtrA})$-dependent formate hydrogen lyase activity by a cloned Thiobacillus ferrooxidans ntr $A$ gene. $J$ Bacteriol 172, 4399-4406.

Birkman, A., Sawers, R. G. \& Bock, A. (1987). Factors affecting transcriptional regulation of the formate-hydrogen-lyase pathway of Escherichia coli. Arch Microbiol 148, 44-51.

Birnboim, H. C. \& Doly, J. (1979). A rapid alkaline extraction procedure for screening recombinant plasmid DNA. Nucleic Acids Res 7, 1513-1523.

Brun, Y. V. \& Shapiro, L. (1992). A temporally controlled $\sigma$-factor is required for polar morphogenesis and normal cell division in Caulobacter. Genes \& Dev 6, 2395-2408.

Byrne, C. R., Monroe, R. S., Ward, K. A. \& Kredich, N. M. (1988). DNA sequences of the $c y s K$ regions of Salmonella typhimurium and Escherichia coli and linkage of the cysK regions to ptsH. J Bacteriol 170, 3150-3157.

Castano, I. \& Bastarrachea, F. (1984). $g \ln F-l a c Z$ fusions in Escherichia coli: studies on $g \ln F$ expression and its chromosomal orientation. Mol \& Gen Genet 195, 228-233.

Chen, Y., Fairbrother, W. J. \& Wright, P. E. (1993). Threedimensional structures of the central regulatory proteins of the bacterial phosphotransferase system, HPr and enzyme IIA ${ }^{\text {gle }} . J$ Cell Biocbem 51, 75-82.

Debarbouille, M., Martin-Verstraete, I., Kunst, F. \& Rapoport, G. (1991). The Bacillus subtilis sigL gene encodes an equivalent of $\sigma^{54}$ from Gram-negative bacteria. Proc Natl Acad Sci USA 88, 9092-9096.

De Bruijn, F. J. \& Ausubel, F. M. (1983). The cloning and characterisation of the $g \ln F(n \operatorname{tr} A$ ) gene of Klebsiella pneumoniae : role of $g \ln F(n \operatorname{tr} A)$ in the regulation of nitrogen fixation (nif) and other nitrogen assimilation genes. Mol \& Gen Genet 192, e342-353.

De Reuse, H., Roy, A. \& Danchin, A. (1985). Analysis of the $p t s H-p t s I-c r r$ region in Escherichia coli K12: nucleotide sequence of the ptsH gene. Gene 35, 199-207.

Deutscher, J., Pevec, B., Beyreuther, K., Kiltz, H. \& Hengstenberg, W. (1986). Streptococcal phosphoenolpyruvate-sugar phosphotransferase system: amino acid sequence and site of ATP-dependent phosphorylation of HPr. Biochemistry 25, 6543-6551.

Devereux, J., Haeberli, P. \& Smithies, O. (1984). A comprehensive set of sequence analysis programs for the VAX. Nucleic Acids Res 12, 387-395.

Dixon, R. (1986). The $x y l A B C$ promoter from the Pseudomonas putida TOL plasmid is activated by nitrogen regulatory genes in Eschericbia coli. Mol \& Gen Genet 203, 129-136.

Eisermann, R., Fischer, R., Kessler, U., Neubauer, A. \& Hengstenberg, W. (1991). Staphylococcal phosphoenolpyruvatedependent phosphotransferase system. Purification and proteir sequencing of the Staphylococcus carnosus histidine-containing protein, and cloning and DNA sequencing of the ptsH gene. Eur I Biocbem 197, 9-14.

Fischer, R., Eisermann, R., Reiche, B. \& Hengstenberg, W. (1989). Cloning, sequencing and overexpression of the mannitol-specific enzyme-III-coding gene of Staphylococcus carnosus. Gene 82, 249-257.

Frey, J., Bagdasarian, M., Feiss, D., Franklin, F. C. H. \& Deshusses, J. (1983). Stable cosmid vectors that enable the introduction of cloned fragments into a wide range of Gram-negative bacteria. Gene 24, 299-308.

Frischauf, A.-M., Lehrach, H., Poustka, A. \& Murray, N. (1983). Lambda replacement vectors carrying polylinker sequences. $J \mathrm{Mol}$ Biol 170, 827-842.

Gagnon, G., Vadeboncoeur, C., Levesque, R. C. \& Frenette, M. (1992). Cloning, sequencing and expression in Eschericbia coli of the $p t s I$ gene encoding enzyme I of the phosphoenolpyruvate:sugar phosphotransferase transport system from Streptococcus salivarius. Gene 121, 71-78.

Geerse, R. H., Izzo, F. \& Postma, P. W. (1989). The PEP: fructose phosphotransferase system in Salmonella typhimurium: FPr combines EnzymeIII $^{\text {Fru }}$ and pseudo-HPr activities. Mol \& Gen Genet 216, 517-525.

Gonzy-Treboul, G., Zagorec, M., Rain-Guion, M.-C. \& Steinmetz, M. (1989). Phosphoenolpyruvate: sugar phosphotransferase system of Bacillus subtilis: nucleotide sequence of $p t s X, p t s H$ and the $5^{\prime}$-end of $p t s I$ and evidence for a $p t s H I$ operon. Mol Microbiol 3, 103-112.

Hirschman, J., Wong, P.-K., Sei, K., Keener, J. \& Kustu, S. (1985). Products of nitrogen regulatory genes $n \operatorname{tr} A$ and $n \operatorname{tr} C$ of enteric bacteria activate $g \ln A$ transcription in vitro: evidence that $n \operatorname{tr} A$ is a $\sigma$ factor. Proc Natl Acad Sci US A 82, 7525-7529.

Hudson, G. S. \& Davidson, B. E. (1984). Nucleotide sequence and transcription of the phenylalanine and tyrosine operons of Escherichia coli K12. J Mol Biol 180, 1023-1051.

Hunt, T. P. \& Magasanik, B. (1985). Transcription of $g \ln A$ by purified Escherichia coli components: core RNA polymerase and the products of $g \ln F, g \ln G$ and $g \ln L$. Proc Natl Acad Sci USA 82, 8453-8457.

Imaishi, H., Gomada, M., Inouye, S. \& Nakazawa, A. (1993). Physical map location of the rpo $N$ gene of Escherichia coli. J Bacteriol 175, 1550-1551.

Inouye, S., Yamada, M., Nakazawa, A. \& Nakazawa, T. (1989). Cloning and sequence analysis of the $n \operatorname{tr} A(r p o N)$ gene of Pseudomonas putida. Gene 85, 145-152.

Ishimoto, K. S. \& Lory, S. (1989). Formation of pilin in Pseudomonas aeruginosa requires the alternative sigma factor (RpoN) of RNA polymerase. Proc Natl Acad Sci USA 86, 1954-1957.

Jagura-Burdzy, G., Ibbotson, J. P. \& Thomas, C. M. (1991). The korF region of broad-host-range plasmid RK2 encodes two polypeptides with transcriptional repressor activity. J Bacterio/ 173, 826-833.

Jones, R. \& Haselkorn, R. (1989). The DNA sequence of the Rbodobacter capsulatus $n \operatorname{tr} A, n \operatorname{tr} B$ and $n \operatorname{tr} C$ gene analogues required for nitrogen fixation. Mol \& Gen Genet 215, 507-516.

Kahn, M., Kolter, R., Thomas, C., Figurski, D., Meyer, R., Remaut, E. \& Helinski, D. R. (1979). Plasmid cloning vehicles derived from plasmids ColE1, R6K and RK2. Methods Enzymol 68, 268-280.

Karin, M. \& Smeal, T. (1992). Control of transcription factors by signal transduction pathways: the beginning of the end. Trends Biocbem Sci 17, 418-422.

Karn, J., Brenner, S., Barnett, L. \& Cesareni, G. (1980). Novel bacteriophage $\lambda$ cloning vector. Proc Natl Acad Sci USA 77, 5172-5176.

Kohler, T., Cayrol, J. M., Ramos, J. L. \& Harayama, S. (1989). Nucleotide and deduced amino acid sequence of the RpoN $\sigma$-factor of Pseudomonas putida. Nucleic Acids Res 17, 10125.

Kullik, I., Fritsche, S., Knobel, H., Sanjuan, J., Hennecke, H. \& Fischer, H. (1991). Bradyrbizobium japonicum has two differentially regulated, functional homologs of the $\sigma^{54}$ gene $(r p o N)$. J Bacteriol 173, 1125-1138.

Kustu, S., Santero, E., Keener, J., Popham, D. \& Weiss, D. (1989). Expression of $\sigma^{54}(n \operatorname{tr} A)$-dependent genes is probably united by a common mechanism. Microbiol Rev 53, 367-376.

Laemmli, U. K. (1970). Cleavage of structural proteins during the assembly of the head of bacteriophage T4. Nature 227, 680-685.

Lee, C. A. \& Saier, M. H. (1983). Mannitol-specific Enzyme II of the bacterial phosphotransferase system. J Biol Chem 258, 10761-10767. 
McKenny, K., Shimatake, H., Court, D., Schmeissner, U., Brady, C. \& Rosenberg, M. (1981). A system to study promoters and terminator signals recognized by Escherichia coli RNA polymerase. In Gene Amplification and Analysis, vol. II, pp. 383-415. Edited by J. C. Chirikjian \& T. S. Papas. Amsterdam: Elsevier.

Meijer, W. G. \& Tabita, F. R. (1992). Isolation and characterization of the nifUSVW-rpoN gene cluster from Rhodobacter sphaeroides. $J$ Bacteriol 174, 3855-3866.

Merrick, M. J. \& Coppard, J. R. (1989). Mutations in genes downstream of the rpoN gene (encoding $\sigma^{54}$ ) of Klebsiella pneumoniae affect expression from $\sigma^{54}$-dependent promoters. Mol Microbiol 3, $1765-1775$

Merrick, M. J. \& Gibbins, J. R. (1985). The nucleotide sequence of the nitrogen regulation gene ntrA of Klebsiella pneumoniae and comparison with conserved features in bacterial RNA polymerase sigma factors. Nucleic Acids Res 21, 7607-7620.

Merrick, M. J. \& Stewart, W. D. P. (1985). Studies on the regulation and function of the Klebsiella pneumoniae ntrA gene. Gene 35, 297-303.

Merrick, M. J., Gibbins, J. \& Toukdarian, A. (1987). The nucleotide sequence of the sigma factor $n \operatorname{tr} A(r p o N)$ of Azotobacter vinelandii: analysis of conserved regions in NtrA proteins. Mol \& Gen Genet 210, 323-330.

Merrick, M., Jones, D. H. A. \& Thomas, C. M. (1993). Location of the rpoN gene on the physical map of Escherichia coli. J Bacteriol 173, $1548-1549$

Orchard, L. M. \& Kornberg, H. L. (1990). Sequence similarities between the gene specifying 1-phosphofructokinase ( $\mathrm{fr} K \mathrm{~K}$ ), genes specifying other kinases in Escherichia coli $\mathrm{K} 12$, and lac $\mathrm{C}$ of Staphylococcus aureus. Proc R Soc Lond B 242, 87-90.

Popham, D. L., Keener, J. \& Kustu, S. (1991). Purification of the alternate $\sigma$ factor, $\sigma^{54}$, from Salmonella typhimurium and characterization of the $\sigma^{54}$-holoenzyme. J Biol Chem 266, 19510-19518.

Pries, A., Priefert, H., Kruger, N. \& Steinbuchel, A. (1991). Identification and characterization of two Alcaligenes eutrophus gene loci relevant to the poly ( $\beta$-hydroxybutyric acid)-leaky phenotype which exhibit homology to ptsH and ptsI of Escherichia coli. $J$ Bacteriol 173, 5843-5853.

Reizer, J., Deutscher, J., Grenier, F., Thompson, J., Mengstenberg, W. \& Saier, W. H. (1988). The phosphoenolpyruvate:sugar phosphotransferase system in Gram-positive bacteria: properties, mechanism and regulation. CRC Crit Rev Microbiol 15, 297-338.

Reizer, J., Reizer, A., Saier, M. H. \& Jacobsen, G. R. (1992). A proposed link between nitrogen and carbon metabolism involving protein phosphorylation in bacteria. Protein Sci 1, 722-726.

Reizer, J., Romano, A. H. \& Deutscher, J. (1993). The role of phosphorylation of $\mathrm{HPr}$, a phosphocarrier protein of the phosphotransferase system, in the regulation of carbon metabolism in Gram-positive bacteria. J Cell Biochem 51, 19-24.

Ronson, C. W., Nixon, B. T., Albright, L. M. \& Ausubel, F. M. (1987). Rhizobium meliloti ntr $A$ is required for diverse metabolic functions. J Bacterial 169, 2424-2431.

Sadaie, Y., Takamatsu, H., Nakamura, K. \& Yamane, K. (1991). Sequencing reveals similarity of the wild-type $d v^{+}$gene of Bacillus subtilis to the Eschericbia coli gene. Gene 98, 101-105.

Saier, M. H. (1993). Introduction: protein phosphorylation and signal transduction in bacteria. $J$ Cell Biochem 51, 1-6.
Saier, M. H. \& Reizer, J. (1992). Proposed uniform nomenclature for the proteins and protein domains of the bacterial phosphoenolpyruvate:sugar phosphotransferase system. J Bacteriol 174, 1433-1438.

Sambrook, J., Fritsch, E. F. \& Maniatis, T. (1989). Molecular Cloning. A Laboratory Manual, 2nd edn. Cold Spring Harbor, NY: Cold Spring Harbor Laboratory.

Sancar, A., Hack, A. M. \& Rupp, W. D. (1978). Simple method for identification of plasmid-coded proteins. J Bacteriol 137, 692-693.

Sanger, F., Nicklen, S. \& Coulsen, A. R. (1977). DNA sequencing with chain-terminating inhibitors. Proc Natl Acad Sci USA 74, 5463-5467.

Saraste, M., Sibbald, P. R. \& Wittinghofer, A. (1990). The P-loop a common motif in ATP- and GTP-binding proteins. Trends Biol Sci 15, 430-434.

Sasse-Dwight, S. \& Gralla, J. D. (1990). Role of eukaryotic-type functional domains found in the prokaryotic enhancer receptor factor $\sigma^{54}$. Cell 62, 945-954.

Shingler, V. \& Thomas, C. M. (1984). Analysis of the $\operatorname{trf} A$ region of broad host range plasmid RK2 by transposon mutagenesis and identification of polypeptide products. J Mol Biol 175, 523-529.

van Slooten, J. C., Cervantes, E., Broughton, W. J., Wong, C. H. \& Stanley, J. (1990). Sequence and analysis of the rpoN sigma factor gene of Rbizobium sp. strain NGR234, a primary coregulator of symbiosis. J Bacteriol 172, 5563-5574.

Stewart, V. J., Parales, J. \& Merkel, S. M. (1989). Structure of the genes narL and nar $X$ of the nar locus in Escherichia coli $\mathrm{K} 12$. J Bacteriol 171, 2229-2234.

Titgemeyer, F., Eisermann, R., Hengstenberg, W. \& Lengeler, J.W. (1990). The nucleotide sequence of $p t s H$ from Klebsiella pneumoniae. Nucleic Acids Res 18, 1898.

Walker, J. E., Saraste, M., Runswick, M. J. \& Gay, N. J. (1982). Distantly related sequences in the $\alpha$ - and $\beta$-subunits of ATP synthase, myosin, kinases and other ATP-requiring enzymes and a common nucleotide binding fold. EMBO J 1, 945-951.

Warrelmann, J., Eitinger, M., Schwartz, E., Romermann, D. \& Friedrich, B. (1992). Nucleotide sequence of the $r p o N(b n o)$ gene cluster of Alcaligenes eutrophus: evidence for a conserved gene cluster. Arch Microbiol 158, 107-114.

Wittekind, M., Rajagopal, P., Branchini, B. R., Reizer, J., Saier, M. H. \& Klevit, R. E. (1992). Solution structure of the phosphocarrier protein HPr from Bacillus subtilis by two-dimensional NMR spectroscopy. Protein Sci 1, 1363-1376.

Wu, L. F., Tomich, J. M. \& Saier, M. H. (1990). Structure and evolution of a multidomain multiphosphoryl transfer protein. Nucleotide sequence of the $f r u B(H I)$ gene in Rhodobacter capsulatus and comparisons with homologous genes from other organisms. J Mol Biol 213, 687-703.

Yanisch-Perron, C., Vieira, J. \& Messing, J. (1985). Improved M13 phage cloning vectors and host strains: nucleotide sequences of the M13mp18 and pUC19 vectors. Gene 33, 103-119.

Yu, G. \& Hong, J. (1986). Identification and nucleotide sequence of the activator gene of the externally induced phosphoglycerate transport system of Salmonella typhimurium. Gene 45, 51-57.

Received 15 September 1993; revised 12 November 1993; accepted 22 November 1993. 